FOLIA HISTORICA CRACOVIENSIA, 21: 2015, s. 311-314

DOI: http://dx.doi.org/10.15633/fhc.1742

Natalia Krupa

Uniwersytet Papieski Jana PawŁa il w Krakowie

\title{
Pracownia Badań i Konserwacji Tkanin Zabytkowych na Uniwersytecie Papieskim Jana Pawła II w Krakowie
}

Pracownia Badań i Konserwacji Tkanin Zabytkowych utworzona została w 2012 roku na Uniwersytecie Papieskim Jana Pawła II, jako jedna z jednostek Instytutu Historii Sztuki i Kultury na Wydziale Historii i Dziedzictwa Kulturowego. Z dniem podjęcia uchwały przez Senat Uniwersytetu Papieskiego Jana Pawła II pracownia rozpoczęła działalność dydaktyczną, naukowo-badawczą i konserwatorską związaną z opieką nad zbiorami tekstyliów kościelnych z obszaru Krakowa i Małopolski.

Ustalenie datowania tkanin zabytkowych opiera się przede wszystkim na dogłębnej analizie porównawczej przemian stylowych zachodzących we wzornictwie epoki. Zapoznanie się z historią danego obiektu i identyfikacja jego atrybucji pozwalają umiejscowić go w pewnych ramach czasowych szerokiego kontekstu historycznego. Chęć uzyskania precyzji w datowaniu zabytków, ocenie technologii produkcji czy analizie stanu zachowania pociąga jednak za sobą konieczność rekonstrukcji historii warsztatu technologicznego typowego dla wspomnianego okresu przy zastosowaniu nowoczesnych technik laboratoryjnych doskonalonych w ośrodkach naukowych.

W pracowni duży nacisk kładziony jest na prowadzenie badań i przygotowywanie dokumentacji procesu konserwatorskiego, zawierającej informacje na temat historii obiektu, techniki wykonania, technologii produkcji, przemian stylowych zachodzących we wzornictwie i hafciarstwie epoki czy stanu zachowania. Tkaniny zabytkowe stanowią cenny materiał badawczy, który - przy wykorzystaniu właściwych narzędzi i metod analizy - pozwala zebrać szereg ważnych informacji potwierdzających fakty historyczne. Drogą do pozyskania szczególnie istotnych danych, niemożliwych do zdobycia za pomocą tradycyjnych metod z warsztatu historyka sztuki, jest interdyscyplinarna współpraca naukowa.

Dzięki wyposażeniu pracowni w odpowiednią aparaturę i przygotowaniu merytorycznemu konserwatorów możliwe jest badanie tkanin w laboratorium 
jednostki lub poza nią ( $u$ właściciela zabytku, w miejscu jego przechowywania lub eksponowania), przy użyciu specjalistycznego sprzętu terenowego. W toku podejmowanych działań gromadzone są informacje na temat techniki wykonywania tkanin, stanu ich zachowania, procesów degradacji, morfologii surowców i ich identyfikacji.

Nowatorskie możliwości techniczne związane są z dokumentowaniem morfologii powierzchni tkanin zabytkowych przy zastosowaniu nowoczesnego automatycznego mikroskopu cyfrowego do pracy w terenie, wyposażonego w oprogramowanie do badania tekstyliów w obrazowaniu 3D (mikroskop Smartzoom 5.1 firmy Zeiss).

Badaniom prowadzonym niezależnie na terenie pracowni towarzyszą analizy realizowane we współpracy z jednostkami zewnętrznymi. 


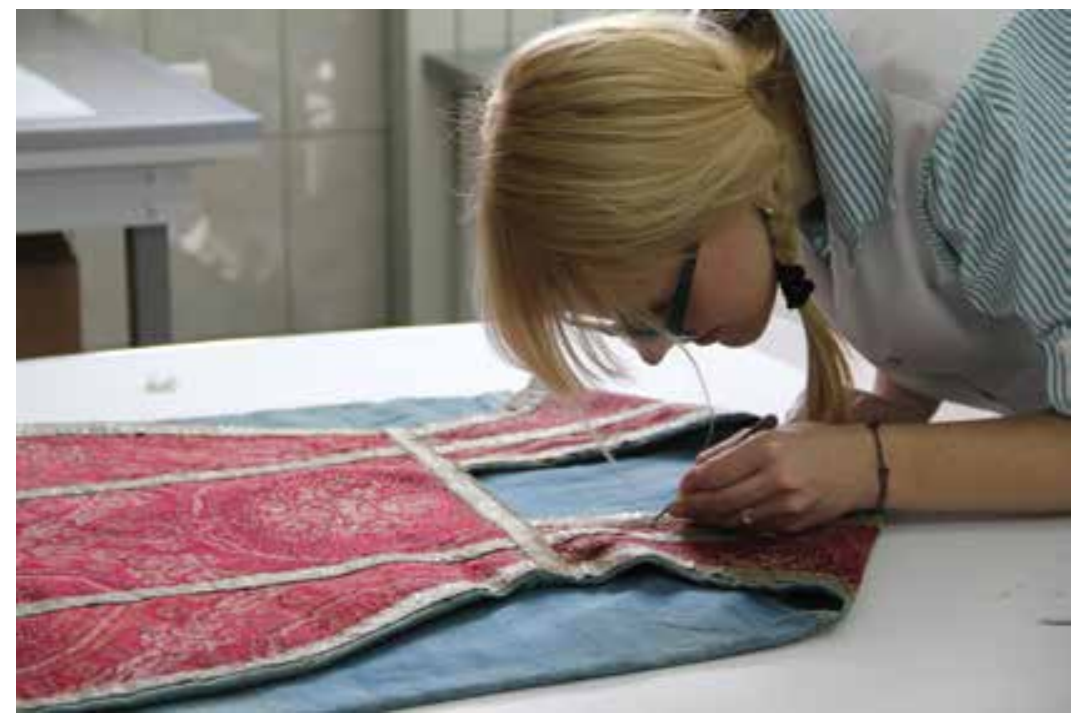

Fot. 1 - Ornat z kościoła pw. Świętych Apostołów Piotra i Pawła w Krakowie, po konserwacji, na zdjęciu Anna Zięba, fot. Natalia Krupa

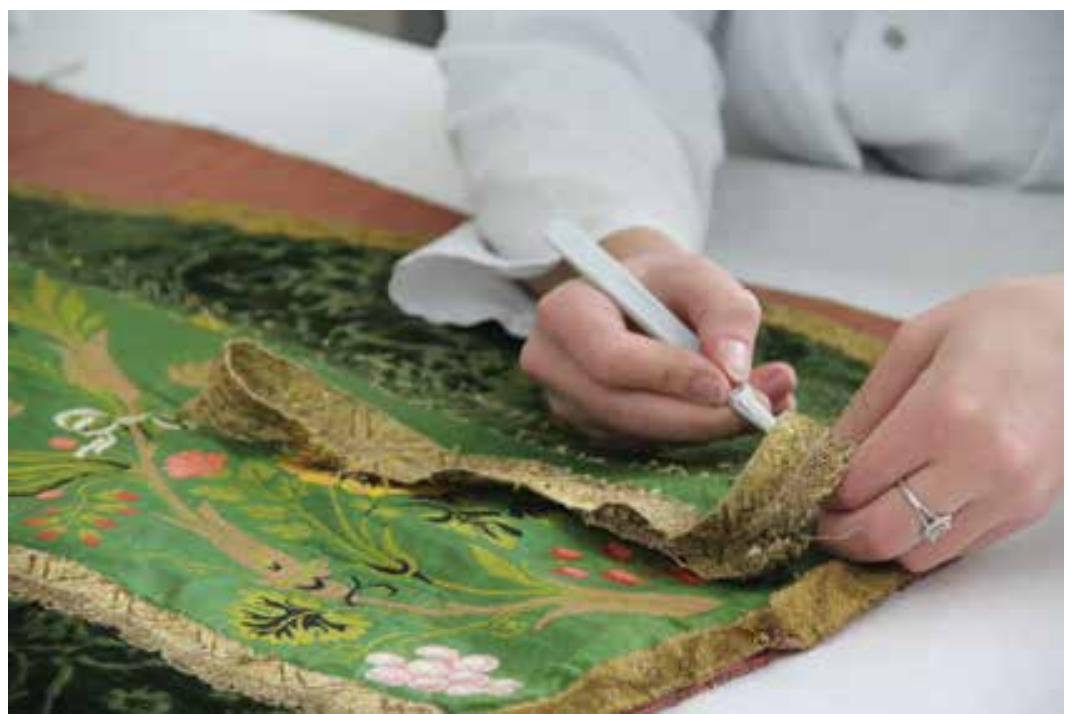

Fot. 2 - Ornat ze zbiorów parafii pw. Szymona i Judy Tadeusza w Kozach, demontaż obiektu, fot. Natalia Krupa 


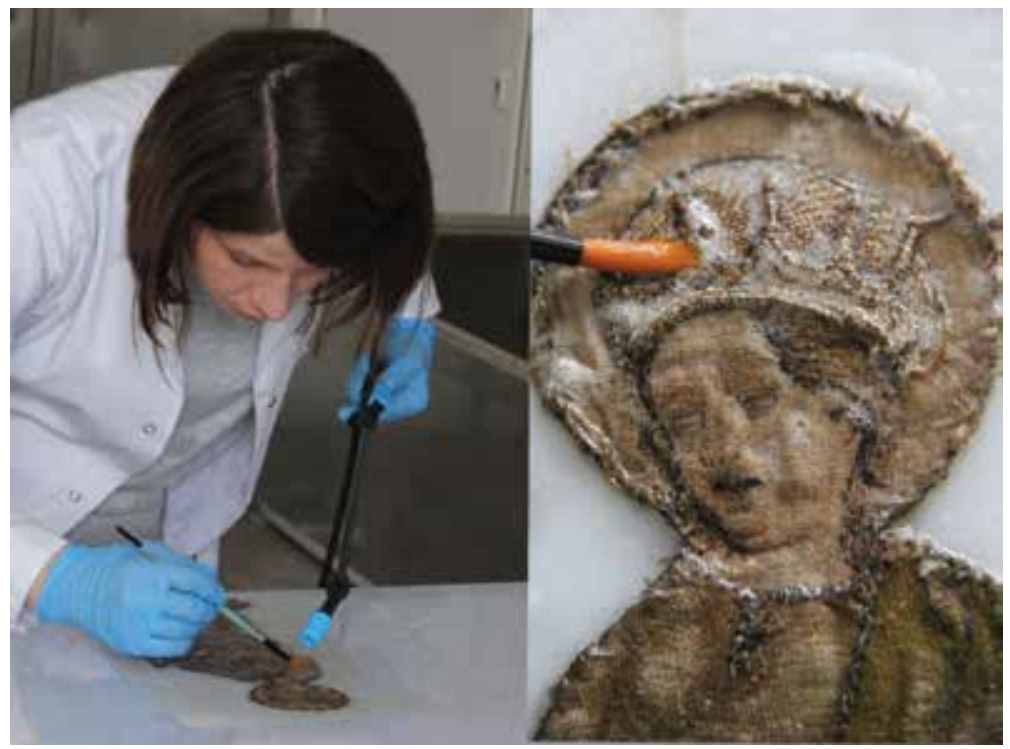

Fot. 3 - Fragment haftu z ornatu z późnogotycka kolumną ze zbiorów parafii pw. Świętej Katarzyny Aleksandryjskiej w Wolbromiu, proces czyszczenia na mokro, na zdjęciu Natalia Krupa, fot. Łukasz Krupa

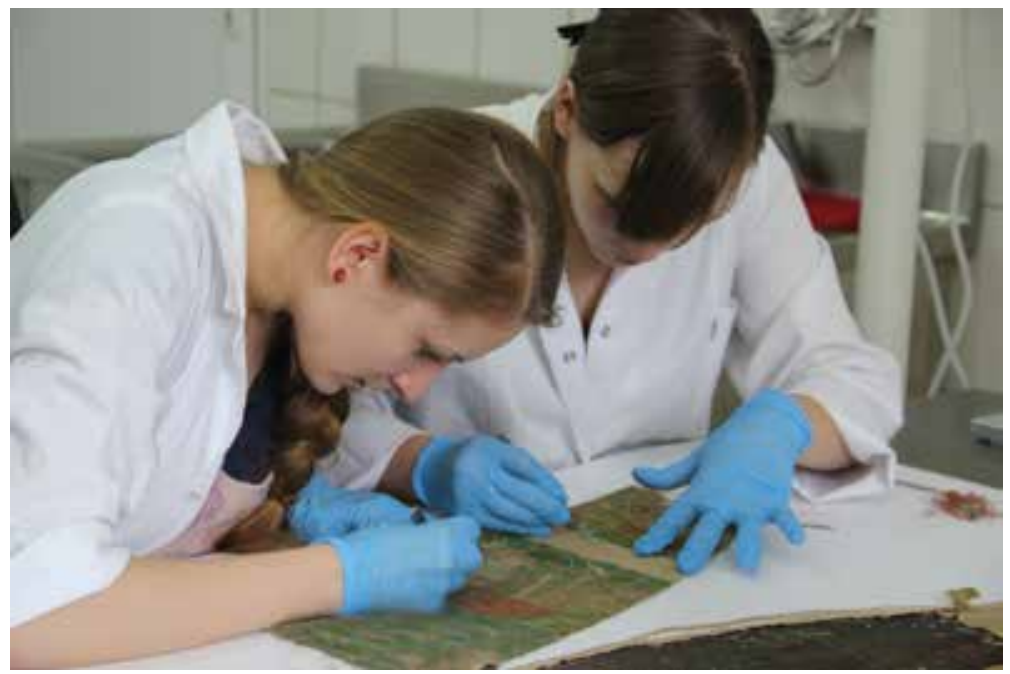

Fot. 4 - Fragment ornatu ze zbiorów parafii pw. Świętej Katarzyny Aleksandryjskiej w Wolbromiu, demontaż obiektu, na zdjęciu Katarzyna Turczanik, Magdalena Magryś, fot. Natalia Krupa 